\title{
A STUDY ON THE CONCEPT AND CAUSES OF DESTINATION REJECTION
}

\author{
Res. Ast. Yusuf KARAKUŞ* \\ Nevşehir Hacı Bektaş Veli University, Tourism Faculty, Nevşehir, Turkey (ykarakus@nevsehir.edu.tr) \\ Lecturer Nevzat KALAY \\ Nevşehir Hacı Bektaş Veli University, School of Foreign Languages, Nevşehir, Turkey (nevzat@nevsehir.edu.tr)
}

\begin{abstract}
During the process of consumer's decision of purchase, the individual is assumed to choose the most appropriate product. Thus, the products which do not have the feature of being the most appropriate product are not preferred. However, in some cases the consumers can refuse the product for some reasons. The point to be emphasized here is the difference between not preferring and refusing. The concept of destination rejection which is a consumer behaviour, and which can be seen in destinations as a touristic product is the subject of this study. When the literature is reviewed, it is noticed that there is no study about refusing destinations (in terms of anti-consumption) though there are studies about preference of destinations. Thanks to this study which focuses on the factors leading to destination rejection, we also aim to contribute towards filling this gap in literature. In this study in which the Cappadocia Region is taken up, the factors which can lead to destination rejection are put in order according to their level of significance through AHP method. The aim of the study is to help the concept of destination rejection to be understood by local and national administrations and all other stakeholders. And also we aim to contribute to the filling of the gap in the literature and as well as recommend contemporary work area for future studies.
\end{abstract}

Keywords: Destination Rejection, AHP, Tourism.

\section{DESTINASYON KARŞITLIĞI KAVRAMI VE SEBEPLERI ÜZERİNE BİR ÇALIŞMA}

\section{ÖZET}

Tüketicinin, alternatif ürünler arasından en uygun olan ürünü seçtiği varsayılmaktadır. Dolayısıyla uygun olma özelliğini taşımayan ürünlerin tercih edilmemesi söz konusudur. Ancak bazı durumlarda tüketiciler bir takım sebeplerden dolayı ürünü reddedebilmektedir. Bu noktada vurgulanmast gereken unsur, tercih etmeme ile reddetme arasındaki farktır. Turistik bir ürün olarak destinasyonlarda da gerçekleşebilecek bir tüketici davranışı olan destinasyon karşıtllğ̆ kavramı bu çalışmanın konusunu oluşturmaktadır. Literatürde, destinasyonların tercih edilmesine yönelik çalışmaların olmasına ră̆men reddedilmesine yönelik bir çalışmaya (tüketim karşıtlı̆̆ı perspektifinden) rastlanmamıştır. Destinasyon karşıtlı̆̆ına neden olabilecek unsurların ortaya çıkarılmaya çalışıldı ğ bu çalışma sayesinde literatürdeki boşluğun da doldurulmasına katkı să̆lanması amaçlanmıştır. Kapadokya bölgesinin ele alındı ğı çalışmada AHP yöntemi ile destinasyon karşıtlığına neden olabilecek unsurlar önem derecesine göre sıralanmıştır. Çalışmanın amacı, destinasyon karşıtlı̆̆ı kavramının yerel ve ulusal yöneticiler ve diğer tüm paydaşlar tarafindan anlaşılmasıdır. Aynı zamanda, literatürdeki mevcut boşluğun kapanmasına bir katkı sağlamak ve gelecek çalışmalara güncel bir çalışma alanı önermek amaçlanmıştır.

Anahtar Kelimeler: Destinasyon Karşıtlı $\breve{g}$, AHP, Turizm.

\footnotetext{
* Corresponding author
}

www.ijmeb.org ISSN:2147-9208 E-ISSN:2147-9194

http://dx.doi.org/10.17130/ijmeb.2017331320

Received: 11.05.2016, Accepted: 26.04.2017 


\section{Introduction}

Various factors such as technological developments, removal of economic borders gradually, decline in work hours, rise in level of income, and living standard give rise to an increase in the interest in tourism activities. According to the data by the Ministry of Culture and Tourism, Turkey was visited by approximately 35,5 million foreign tourists in 2015 . As Çetintaş \& Bektaş (2008) mentions, tourism revenues are significant for the growth of national economy. As tourism revenues is an export item, it is important in terms of the balance of foreign trade. Moreover, with its multiplier effect, it invigorates the economy. The positive effect of tourism activities can be seen not only in economy but also in other areas such as culture, society, environment. Therefore, it is the duty of researchers, local and national governments, business executives, even the whole society to support tourism activities.

When the tourism potential of our country is considered, it is known that all significant attractions for visitors as destination exist in our country. Kutvan Kutvan order these attractions as follows: "natural attractions, climate, architectural features, festivals, local features, people's attitude towards tourists, important historical ruins, religious works, historical works, sport activities, cultural activities, health and recreational facilities, night recreations, shopping facilities, infrastructure, food and accommodation facilities for tourists" (Kutvan \& Kutvan, 2013). Although it is a country having such a huge tourism potential, Turkey is not at a welldeserved place in terms of the quantity and socioeconomic status of demand. When literature is reviewed regarding this issue, it is seen that the methods to attract visitors are studied extensively. The fact that there is no local study about the reason why a destination can be refused by consumers is indicative of a serious gap in this subject. Although there are a few foreign studies on this subject (Lawson \& Thyne, 2001; Sönmez \& Graefe, 1998), there is no study revealing the behaviour of anti-consumption that can be developed against a destination. In the studies, either certain dimensions of destination rejection or the behaviour of anticonsumption pertaining to a specific destination are studied. The aim of this study is to explain why individuals may reject some destinations while purchasing decision of the consumers at the stage of destination selection.For a certain destination, identifying the ideas of individuals who does not visit the destination is quite difficult. For this reason, in this study, the ideas of experts (especially decision makers in tourism industry) are uncovered in terms of the concept of destination rejection. And also we aim to contribute to the filling of the gap in the literature and it will be contemporary work area for future studies.

\section{Concept of Destination Rejection}

It is better first to focus on the behaviour of destination rejection, and then on the concept of anti-consumption. The general definition of anti-consumption can be expressed as "refusing consumption or opposing consumption" (Lee, Fernandez \& Hyman, 2009). It is stated in the study by Cherrier that one of the most prominent indicators of anti-consumption behaviour is consumer resistance (Cherrier, 2009). It is pointed out that such resistances may indicate general consumption, or indicate certain brands or products. The concepts related to the concept of anti-consumption can be stated as follows: Consumer resistance (Penaloza \& Price, 1993; Roux, 2007), consumer uprisings (Austin, Plouffe \& Peters, 2005), avoiding brand 
(Lee, Motion \& Conroy, 2009), political consumption (Delacote \& Montagne-Huck), 2012; Özalpman, 2010) and voluntary simplicity (Shaw \& Moraes, 2009).

According to the study carried out by Choi (Choi, 2011) the individuals' behaviour of anti-consumption is composed of four categories in line with purpose and motive (Figure 1). With respect to motives, the individual can reveal the behaviour of anti-consumption to express his individual values or by accepting the values of the society. With regard to purpose, the individual can reject a certain product or brand or can oppose to the consumption behaviour in general. From this point of view, destination rejection behavior is a kind of anti- consumption to definite destination.

Fatigue anti-consumption individuals are those who are tired of intensive marketing efforts made by businesses, and willing to lead a simple life. As for Trauma anti-consumption individuals, they have a tendency to reject certain future products and brands as they have not been pleased with their previous experiences. Another anti-consumption mass of people are Enlightenment anti-consumption. They protest consumer behaviour generally due to social or environmental reasons. The last type of anti-consumption people covers Activist anticonsumption who react to certain brands or products for general reasons such as social or environmental reasons.

This concept is categorized under four main headings in one of the studies carried out on the concept of anti-consumption (Iyer \& Muncy, 2009). The first two headings cover the opposition that individuals developed against the concept of consumption in general. The first of this classification is the group of people who oppose the concept of consumption generally and reject consumption to decrease consumption. Another group is the one that looks for a simple life and that believes that consumption is necessary only when it is really needed. The individuals in this group believe that those who overconsume may suffer from negative emotions such as fatigue, unhappiness or disappointment. The other two classifications refer to a behaviour of rejection developed against a brand or product. The individuals in the third classification are the ones who believe that a certain product or brand gives harm to the society,

\section{Figure 1: Classification of Anti-Consumption}

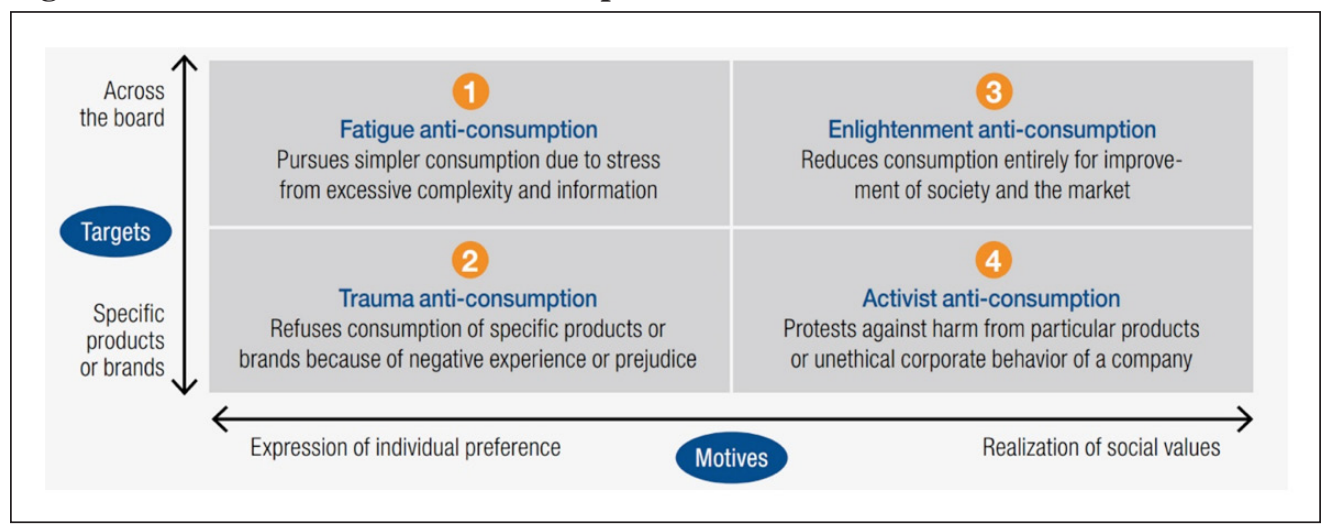

Reference: Choi, S.-H. (2011). Anti-consumption Becomes a Trend. SERI Quarterly, 4(3), 117-120. 
and thus reject that product or brand. The individuals in the last category are the ones that reject a certain product or brand due to personal reasons such as negative experiences they had in the past.

In the study, it is stated that initial needs within Maslow's hierarchy of needs may be met through consumption behaviour, but self-actualization needs are related to simplicity and the behaviour of anti-consumption may be more satisfying in terms of this need. Also, it is thought that there is a positive interaction between anti-consumerists and self consciousness in general. Research findings support the expected interaction with global anti-consumption, they are negative for the individuals who reject consumption for a simple life. Iyer \& Muncy (2009) examined anti-consumption in terms of society and individuals, and aimed to be a guide for future studies.

Lee, Motion \& Conrov (2009) studied brand evasion as anti-consumption in their study. The question of the study is why people avoid purchasing certain brands though they have the means to purchase. 23 people participated in the survey, and data were collected through indepth analysis method. Each participant was shown certain brands, and which ones s/he did not prefer and the reasons behind this preference were examined. In line with the data obtained, the reasons of brand evasion were grouped under three headings. One of these is called experimental evasion. This evasion stems from the individual's previous experiences. Second of these is identity evasion and the reason for this kind of evasion is incompatibility of their identities. The last evasion is ethical evasion. As the individuals think that the brand has social damages, they do not buy that kind of brand. It is stated that the cause of experimental evasion is unfulfilled expectations, the cause of identity evasion is symbolic identity incompatibility and the cause of ethical evasion is ideological incompatibility. In the study, managers were given advice on how to cope with the problem of brand evasion.

Ventura examined the concept of anti-consumption in terms of white goods (Ventura, 2013). The participants were asked whether they display anti-consumption behavior through focus group discussion. If anti-consumption was in question, the reason for this, and in future whether they would buy again the goods they had not bought were asked. The anti-consumption behaviours are studied in terms of experimental evasion, identity evasion, ethical evasion, under evaluation evasion and dealer-distributor evasion. The findings were evaluated and managers of white goods were given advice accordingly.

In this study, the anti-consumption behaviour is examined in terms of tourist consumers. The reasons for rejecting certain destinations when the individuals constituting tourist demand choose among alternatives during the process of purchasing constitute the subject of this study. In this sense, the anti-consumption behaviour that consumers display can be defined as follows: it is the state of rejection of certain destinations by individuals who create tourist demand (those having money, time, means and willingness) during the stage of destination selection. In this sense, one of the critical points is that the individual should meet necessary conditions (time, economic power, willingness and means) for a touristic visit. The concept of anti-consumption in scope is individual's rejecting one or some of the alternative destinations due to certain reasons.The fundamental circumstance is the difference between rejecting the purchasing and not preferring. In a situation that a purchaser not prefer the destination means that destination is 
an alternative and evaluated; nevertheless it is not purchased. It is possible that a case can be the reason of rejection and also the reason of not preferring. Also, for destination, alternative destinations should be equal to each other. Individual's rejecting one destination because s/ he prefers another destination is out of the scope of this study. In order to mention about anticonsumption attitude or behaviour, there should be a direct rejection of that destination rather than preferring better destination as a result of comparison. In this sense, no study is found in local literature. Although there are limited number of sources, there is no study corresponding with the concept of anti-consumption generally.

In the study by Sönmez \& Graefe, tourists' tendencies to go or not to go to certain regions according to their risk perception in their future travels are studied (Sönmez \& Graefe, 1998). The risk factors that may cause tourists not to prefer certain regions are as follows: equipment risk, financial risk, health risk, psychological risk, political instability, physical risks, social risks, terrorism and time risk. Findings of the study indicate that tourists avoid certain destination in situations in which risk perception is high. However, perceived risk is taken up as the cause of anti-consumption in the study. Generally, there are always uncertainities in tourism activities. Thus, there may be risk perception in the destinations which will be visited by individuals for the first time. This situation does not correspond to the behaviour of destinati for that destination, it can be ezplained as not preferring only. Consumers always choose the most convenient one among alternatives during the process of purchase. The alternatives that are not chosen are the result of not preferring, not of anti-consumption behaviour.

In the study by Lawson \& Thyne, the differences in tourists' destination selection, and the probable reasons for not preferring certain destinations among these differences are studied (Lawson \& Thyne, 2001). They grouped the variables under three headings, which may lead tourists not to prefer certain destinations using the data obtained within the scope of the study through in- debth analysis method: crowdedness, cost and danger. The variables in the category of crowdedness are excess of local tourists, excess of foreign tourists and general crowdedness. In the category of cost are expensiveness of travelling, accommodation, shopping and activities. In the category of danger are being dangerous to travel, political incompatibility, cultural incompatibility, language differences and spent money risk variables. In the study a particular correspondence to a specific destination is taken up. Why a specific destination (New Zealand) in line with its present features is not preferred is examined. The study conducted is insufficient to explain in general the behaviour of destination rejection.

The consumers which constitute touristic demand make their decision of purchase by experiencing the process of decision to buy (rational or irrational). In this sense, at the level of destination the ways of supporting purchase to direct the demand are studied widely in the literature. However, in some cases individuals may reject destination directly. Various reasons that lead the tourist consumers to behave in this way may be mentioned. One of these reasons is that the crime rate is high, which is an aspect of this study. Mostly the relationship between the rise in touristic activities and crime is studied in the literature (Alleyne \& Boxill, 2003; Fujii \& Mak, 1979; Van Tran \& Bridges, 2009). While evaluating options during the process of touristic purchase, that is while selecting destination, no study is found on studying the factors that lead consumers to the behaviour of destination rejection, and there are few studies on consumer worry or terrorism (Larsen, Brun \& Øgaard, 2009; Sönmez \& Graefe, 1998). The 
aim of the study is to help the concept of destination rejection to be understood by local and national administrations and all other stakeholders.

\section{Method}

In the study, the concept of destination rejection is evaluated using AHP method and the significance degrees of decision making criteria important for consumers are tried to be determined. A two-stage data collection process was followed to reach the mentioned study objectives. First, in the tourism industry, where 22 experts were interviewed in the first half of 2015, is used to d emonstrate why the individuals can reject a destination. These people are; five tourism academicians, three officers from City Administrations of Nevşehir, four officers from Municipal Authority of Nevşehir, five members of Kaptid (Cappadocia Touristic Hoteliers and Operators Association) and five professional tourist guides. Content analysis was used to determine the factors that may lead to destination rejection behavior. These factors are shown in Table 1.

\section{Table 1: The Factors That May Lead To Destination Rejection Behaviour}

\begin{tabular}{ll}
\hline T1 & Economic instabilities within the country \\
\hline T2 & Terrorist activities in the country or in close neighborhood \\
\hline T3 & High rate of crime in the destination \\
\hline T4 & Attaching less importance to human rights in the country \\
\hline T5 & Attaching no importance to natural environment \\
\hline T6 & Profile of other visitors preferring this destination \\
\hline T7 & Redundant expensiveness of the destination \\
\hline T8 & Excess of health risks projected for the country \\
\hline T9 & Appeal of touristic product to certain people \\
\hline T10 & Socio-cultural structure of local people \\
\hline T11 & Religious belief and religious culture of local people \\
\hline T12 & Language of local people \\
\hline T13 & Biased activities of tour operators and travel agencies \\
\hline T14 & Negative propaganda of other destinations \\
\hline T15 & $\begin{array}{l}\text { Enmity between the country where the tourist lives and the country where the } \\
\text { destination is }\end{array}$ \\
\hline
\end{tabular}

The second stage of the data collection was applied to the same sample. All participants were asked to compare these 15 criteria to each other in terms of general destination rejection behavior. Then they asked to compare for the case of Cappadocia. However all respons were not adequate in consequence of unsatisfactory consistency rate. The same process was repeated to all sample until last quarter of 2016 and provided data from each expert category contains at least two participants. 
Final weights/priority values regarding the consumer expectations are obtained through the arithmetic average of priority values of each decision maker with respect to factors leading to the same destination rejection (Table 5). In Table 2 the sorting of final weights are shown in descending sort.

Table 2: Sorting of Factors That May Lead to Destination Rejection

\begin{tabular}{llc}
\hline T2 & Terrorist activities in the country or in close neighborhood & 0,191386968 \\
\hline T3 & High rate of crime in the destination & 0,132512485 \\
\hline T8 & Excess of health risks projected for the country & 0,117403936 \\
\hline T5 & Attaching no importance to natural environment & 0,078443812 \\
\hline T15 & $\begin{array}{l}\text { Enmity between the country where the tourist lives and the } \\
\text { country where the destination is }\end{array}$ & 0,061807674 \\
\hline T10 & Sconomic instabilities within the country & 0,060581592 \\
\hline T13 & Biased activities of tour operators and travel agencies & 0,058217811 \\
\hline T7 & Redundant expensiveness of the destination & 0,05125606 \\
\hline T11 & Religious belief and religious culture of local people & 0,04689035 \\
\hline T9 & Appeal of Touristic product to certain people & 0,039732748 \\
\hline T4 & Attaching less importance to human rights in the country & 0,037152003 \\
\hline T6 & Profile of other visitors preferring this destination & 0,036920059 \\
\hline T14 & Negative propaganda of other destinations & 0,032941429 \\
\hline T12 & Language of local people & 0,031730034 \\
\hline
\end{tabular}

When table 4 is examined, it is seen obviously that the most significant factors that may lead to corresponding behaviour that tourist consumers may develop against a destination within their decision making process of purchase are "Terrorist activities in the country or in close neighborhood" and "High rate of crime in the destination". On the other hand, as the least important factor that may lead to the behaviour of destination rejection is "The profile of other visitors preferring this destination".

Analytical Hierarchy Process (AHP): The activity of decision making may be said to be the main activity business executives. When it was felt necessary to find some means to help decision making, various means were developed after 1960s (Urfalığlu \& Genç, 2013). While making decisions, it is expected that the most convenient is to be prefered among many alternatives. However, each alternative has its pros and cons. That is why, multi-criteria decision making methods facilitates and accelerates the works of decision makers. Yet, the data that will be input in many decision making mechanisms may be made up of subjective judgments. At this point, AHP is a method that enables subjective judgements by digitizing to translate into objective assessment criteria. The method was developed by L.Saaty (Saaty, 2003). The steps followed in the applicaiton of AHP method are explained in the following paragraphs. 
Presentation of the problem in a hierarchical structure: the first thing to do while using AHP method is to compose a hierarchical structure. First, the ultimate aim is determined within the scope of the research. The alternatives needed to reach the ultimate aim and the criteria that our ultimate aim must have are presented in a hierarchical structure. The ultimate aim is to select the most convenient considering all the criteria. A sample hierarchical structure is given in figure 1 . The hierarchy is composed of six criteria and three alternatives.

In our study, ultimate aim is to determine the sorting the reasons of destination rejection behavior by their weight for the destination Cappadocia. As a result of this each reasons of destination rejection behavior became our criterias. AHP is usually used to choose an alternative through a list. Unlike this, in our study, choosing an alternative is not aimed. Therefore, in this study, there was no alternative destination to Cappadocia.

Composing paired comparison matrices: the data obtained through AHP method are done so through paired comparison. The criteria that the ultimate aim must have are compared one by one amongst themselves. Then, considering criteria, all the existing alternatives are subjected to paired comparison between each other. Subjecting each variable to paired comparison between each other makes the consistency of given answers to be more reliable. While making comparisons the 9 scale (table 1) developed by Saaty is used and with the help of quantitative weights in this scale paired comparison matrices are obtained by digitizing judgment values (Wind \& Saaty, 1980).

Figure 2: Sample of AHP Model

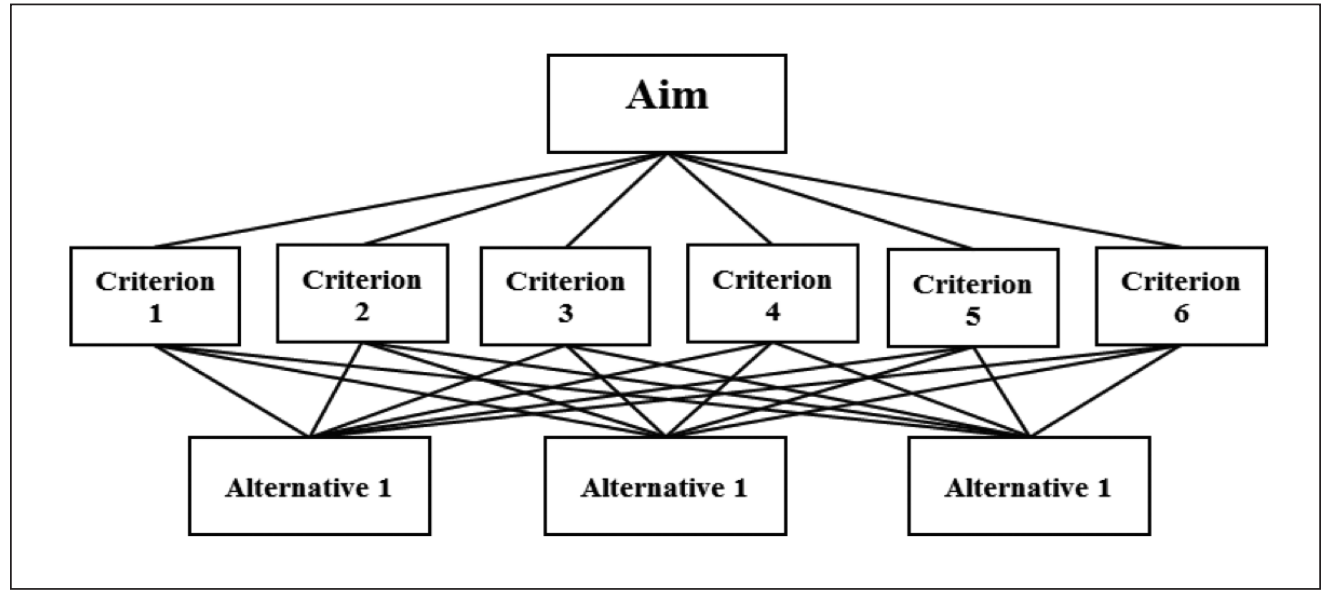

Reference: Saaty, Thomas L. \& Vargas, Luis G. (2012) Models, methods, concepts \& applications of the analytic hierarchy, Springer p.3. 
Table 3: Paired Comparison Scale Used in AHP

\begin{tabular}{|c|c|c|}
\hline No: & Statement scale & Explanation \\
\hline 1 & Both factors are equal in importance & Factors contribute equally \\
\hline 3 & $\begin{array}{l}\text { One of the factors is more important } \\
\text { than the other }\end{array}$ & $\begin{array}{l}\text { As a result of experience and judgments one } \\
\text { of the factors is preferred to the other one }\end{array}$ \\
\hline 5 & $\begin{array}{l}\text { One of the factors is much more } \\
\text { important than the other }\end{array}$ & $\begin{array}{l}\text { One of the factors is strongly preferred to } \\
\text { the other one }\end{array}$ \\
\hline 7 & $\begin{array}{l}\text { One of the factors is considerably } \\
\text { more important than the other }\end{array}$ & $\begin{array}{l}\text { One of the factors is much strongly } \\
\text { preferred to the other one }\end{array}$ \\
\hline 9 & $\begin{array}{l}\text { One of the factors is definitely more } \\
\text { important than the other }\end{array}$ & $\begin{array}{l}\text { One of the factors is undisputedly preferred } \\
\text { to the other one }\end{array}$ \\
\hline $2,4,6,8$ & Intermediate values & $\begin{array}{l}\text { Used to compromise between two } \\
\text { judgments }\end{array}$ \\
\hline
\end{tabular}

Reference: Berrittella, M., La Franca, L., \& Zito, P. (2009). An analytic hierarchy process for ranking operating costs of low cost and full service airlines. Journal of Air Transport Management, 15(5), 249- 255, p. 251.

In a case in which there are $\mathrm{n}$ criteria $(\mathrm{K})$ in total, paired comparison matrix $(\mathrm{A})$ will be like the following example:

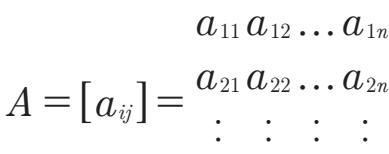

$$
\begin{aligned}
& a_{n 1} a_{n 2} \ldots a_{n n}
\end{aligned}
$$

When the matrix is examined, it is seen that the values are $a_{i j}$. These values show quantitative judgments regarding the comparison between $\mathrm{K}_{\mathrm{i}}$ (i-times criterion) and $\mathrm{K}_{\mathrm{j}}$ ( $\mathrm{j}$-times criterion). For instance, $\mathrm{a}_{12}$ value is a value obtained as a result of the comparison between $\mathrm{K}_{1}$ and $\mathrm{K}_{2}$.

3.Finding priority values of paired comparison matrices: In order to find priority values, sum of priority matrices of each column is obtained. The next step is to divide each item in matrix by the sum of column where matrix is. As a result of the operation the sum of each column must be 1 . Each item within the matrix takes values between zero (0) and one (1). In other words the matrix is normalized. Each line within the obtained normalized matrix is averaged. These averages form a column matrix and show priority values (weights) corresponding each criteria. The following $\mathrm{W}$ matrix is the column matrix in $\mathrm{nx} 1$ type providing priority values.

$$
W=\left[w_{i j}\right]=\begin{gathered}
w_{11} \\
w_{21} \\
: \\
w_{n 1}
\end{gathered}
$$


In other words, the average of each line is the priority value of the criterion that it is attached. The criteria are ordered between each other according to their weights (priority values). The criterion with the highest weight is more important than the others. But, is it possible to use these values immediately? To answer this question we look at the consistency ratio of the paired comparison matrices. If the comparisons in matrices are consistent, then it is possible to use the obtained weights.

4. Calculation of consistency ratio: the early form paired comparison matrix is multiplied by the priority values obtained from this matrix. That is, it is obtained from the multiplicaton of A matrix in nxn type by $\mathrm{W}$ matrix. As a result of this multiplication $\mathrm{R}$ matrix in $\mathrm{nx} 1$ type is obtained.

$$
A_{n x n} W_{n x 1}=\begin{array}{cccccc}
a_{11} & a_{12} & \ldots & a_{1 n} & w_{11} & r_{11} \\
a_{21} & a_{22} & \ldots & a_{2 n} & w_{21} \\
: & \vdots & : & : & : & r_{21} \\
a_{n 1} & a_{n 2} & \ldots & a_{n n} & w_{n 1} & r_{n 1}
\end{array}=R_{n x 1}
$$

Then, each item in $\mathrm{R}$ matrix is divided by the item corresponding it in $\mathrm{W}$ matrix. This operation is shown below, and as a result of division M matrix is obtained.

$$
\begin{gathered}
r_{11} / w_{11} \quad \begin{array}{l}
b_{11} \\
w_{21} / w_{21} \\
:
\end{array} \begin{array}{c}
b_{21} \\
w_{n 1} / w_{n 1}
\end{array}=B_{n x 1} \\
b_{n 1}
\end{gathered}
$$

Now it is possible to calculate 1 max value. And this is the arithmetic mean of the values in B matrix.

$\lambda \max =\frac{b_{11}+b_{21}+\ldots+b_{n 1}}{n}$

We can now calculate Consistency Index (CI):

$$
T \dot{I}=\frac{\lambda \max -n}{n-1}
$$


Consistency Ratio (CR) is a value obtained from the division of CI by Random Index (RI).

$$
T O=\frac{T \dot{I}}{R \dot{I}}
$$

$\mathrm{RI}$ is an index with different values with respect to matrix's size. Random index values with regard to different sizes of matrix are shown in table 2.

In order to test whether the paired comparisons made are consistent, CR is considered. If this ration is equal to 0,1 or smaller than this, it can be said that these paired comparisons are consistent.

Table 4: Random Index Values with Respect to Criteria Number

\begin{tabular}{lccccccc}
\hline $\mathbf{n}$ & $\mathbf{3}$ & $\mathbf{4}$ & $\mathbf{5}$ & $\mathbf{6}$ & $\mathbf{7}$ & $\mathbf{8}$ & $\mathbf{9}$ \\
\hline$R \dot{I}$ & 0.5245 & 0.8815 & 1.1086 & 1.2479 & 1.3417 & 1.4056 & 1.4499 \\
\hline $\mathrm{n}$ & 10 & 11 & 12 & 13 & 14 & 15 & \\
\hline$R \dot{I}$ & 1.4854 & 1.5141 & 1.5365 & 1.5551 & 1.5713 & 1.5838 & \\
\hline
\end{tabular}

Reference: Alonso, J. A., \& Lamata, M. T. (2006). Consistency in the analytic hierarchy process: A new approach. International Journal of Uncertainty, Fuzziness and Knowledge-Based Systems, 14(04), 445-459, 449.

5. Determination of final priority values: finally combined weights or in other words final priority values are found by bringing priority values (weights) obtained throughout hierarchy together. From the top to the bottom of hierarchy the weights in each layer are multiplied. The value obtained as a result of summing up these multiplications is the final priority value of each alternative (Bottero et al, 2011: 1212).

\section{Conclusion and Recommendations}

The share that tourism sector receives in today's world where the place that service sector occupies grows more and more within the economic activities of countries. Also, tourism sector which has a significant place in export proceeds is a golden opportunity for developing and underdeveloped countries. Thus, tourism activities should be improved, in other words, countries should be preferred more by gaining advantage over their rivals as destination. Globalizing world and developing technology make conditions of competition harder, and destinations all over the world become rivals. When the literature is reviewed, it is found out that mostly supportive factors in the selection of destination by tourist consumers are examined.

Researchers studied about forming supportive strategies by the activities of purchase by focusing on the reason why individuals within the process of purchase preferred certain destinations. Yet, in today's world not only the behaviour of purchase but also the behaviour of rejecting purchase are considered when consumer behaviour is mentioned. Therefore, in this study, the behaviour of rejection taking place during destination preference is tried to be explained. 


\begin{tabular}{|c|c|c|c|c|c|c|c|c|c|c|c|c|c|c|c|c|}
\hline 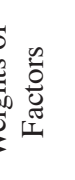 & 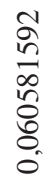 & $\begin{array}{l}\infty \\
0 \\
\infty \\
\infty \\
m \\
\vdots \\
\overrightarrow{0} \\
0\end{array}$ & 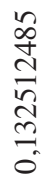 & 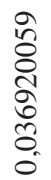 & 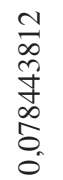 & 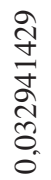 & $\begin{array}{l}\text { n} \\
\text { \&̊ } \\
\infty \\
\infty \\
0 \\
0 \\
0\end{array}$ & 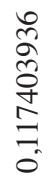 & 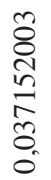 & $\begin{array}{l}\vec{\Xi} \\
\stackrel{\infty}{\sigma} \\
\vec{\sigma} \\
\infty \\
0 \\
0 \\
0\end{array}$ & 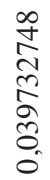 & 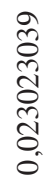 & 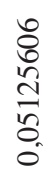 & 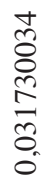 & 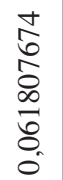 & \\
\hline$\stackrel{n}{=}$ & 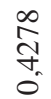 & $\begin{array}{l}8 \\
8 \\
\text { r. } \\
\text { in }\end{array}$ & $\begin{array}{l}8 \\
8 \\
8 \\
\text { i }\end{array}$ & $\begin{array}{l}\text { J } \\
f_{0} \\
0\end{array}$ & 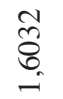 & $\begin{array}{l}\stackrel{2}{2} \\
\stackrel{+}{+} \\
0\end{array}$ & 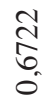 & $\begin{array}{l}8 \\
\varnothing \\
\infty\end{array}$ & $\begin{array}{l}8 \\
8 \\
0 \\
0\end{array}$ & $\begin{array}{l}8 \\
\swarrow \\
\swarrow \\
0\end{array}$ & $\frac{8}{\circ}$ & $\begin{array}{l}\text { J } \\
\text { సे. } \\
0\end{array}$ & $\begin{array}{l}8 \\
n \\
n \\
n\end{array}$ & $\begin{array}{l}\hat{\sigma} \\
\overline{0} \\
0\end{array}$ & $\begin{array}{l}8 \\
8 \\
8\end{array}$ & \\
\hline$\underset{E}{ \pm}$ & $\begin{array}{l}\stackrel{m}{-\infty} \\
\stackrel{\infty}{+}\end{array}$ & 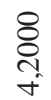 & $\frac{8}{8}$ & $\begin{array}{l}8 \\
8 \\
\infty \\
0\end{array}$ & $\begin{array}{l}8 \\
\frac{8}{2} \\
i\end{array}$ & $\begin{array}{l}\text { त̃ } \\
\infty \\
0 \\
0\end{array}$ & $\begin{array}{l}8 \\
\stackrel{2}{n} \\
\text { ñ. }\end{array}$ & $\begin{array}{l}8 \\
\text { ळ. } \\
\text { m. }\end{array}$ & $\begin{array}{l}8 \\
8 \\
\stackrel{+}{+}\end{array}$ & $\begin{array}{l}\text { तु } \\
\text { Љ }\end{array}$ & $\begin{array}{l}\stackrel{2}{\Omega} \\
\stackrel{2}{\approx}\end{array}$ & 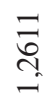 & 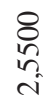 & 8 & $\frac{\stackrel{0}{m}}{\frac{0}{0}}$ & \\
\hline$\stackrel{m}{a}$ & 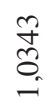 & $\begin{array}{l}8 \\
\text { \& } \\
\text { m. } \\
\text { m. }\end{array}$ & $\begin{array}{l}8 \\
8 \\
0 \\
\text { i } \\
\text { in }\end{array}$ & $\frac{8}{\stackrel{8}{f}}$ & $\begin{array}{l}8 \\
\stackrel{2}{1} \\
-1\end{array}$ & $\begin{array}{l}\frac{1}{2} \\
n \\
0\end{array}$ & 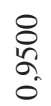 & $\frac{8}{8}$ & $\begin{array}{l}8 \\
0\end{array}$ & $\frac{\stackrel{n}{n}}{\frac{i n}{n}}$ & $\begin{array}{l}\text { ch } \\
\infty \\
\text { તn }\end{array}$ & 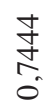 & 8 & 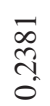 & $\begin{array}{l}\mathbb{J} \\
\text { O্. } \\
\text { On. }\end{array}$ & \\
\hline $\mathcal{O}$ & $\begin{array}{l}\stackrel{n}{n} \\
n \\
n \\
\sim\end{array}$ & $\begin{array}{l}8 \\
\delta \\
\infty \\
0 \\
0\end{array}$ & $\begin{array}{l}8 \\
8 \\
0 \\
+\end{array}$ & $\begin{array}{l}\stackrel{2}{2} \\
\text { ñ } \\
-\end{array}$ & $\begin{array}{l}8 \\
8 \\
8 \\
\text { m. }\end{array}$ & 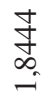 & $\begin{array}{l}\stackrel{m}{\tilde{N}} \\
\stackrel{\sim}{i}\end{array}$ & $\frac{8}{8}$ & $\begin{array}{l}8 \\
\frac{n}{2} \\
i\end{array}$ & $\begin{array}{l}8 \\
\stackrel{n}{\circ} \\
\dot{n}\end{array}$ & 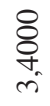 & 8 & $\begin{array}{l}0 \\
n \\
n \\
n \\
0\end{array}$ & 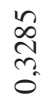 & $\begin{array}{l}\text { ஸे } \\
\mathscr{0} \\
0\end{array}$ & \\
\hline 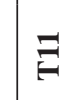 & $\begin{array}{l}\hat{\sigma} \\
\stackrel{2}{=}\end{array}$ & $\begin{array}{l}8 \\
\text { } \\
\text { } \\
\text { f }\end{array}$ & $\frac{8}{8}$ & $\begin{array}{l}\hat{8} \\
\frac{0}{0}\end{array}$ & $\begin{array}{l}8 \\
8 \\
0 \\
i\end{array}$ & 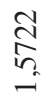 & $\begin{array}{c}\text { થิ } \\
\text { है } \\
\text { त. }\end{array}$ & $\frac{8}{8}$ & $\begin{array}{l}8 \\
\check{n} \\
\end{array}$ & $\begin{array}{l}\stackrel{8}{\circ} \\
ٌ \\
\sim\end{array}$ & 8 & $\begin{array}{l}0 \\
\infty \\
\stackrel{\infty}{0}\end{array}$ & $\frac{\vec{\sigma}}{\hat{\sigma}}$ & $\begin{array}{l}\text { Jे } \\
\text { స్ } \\
0\end{array}$ & $\begin{array}{l}\vec{\infty} \\
\stackrel{5}{0} \\
0\end{array}$ & \\
\hline$\stackrel{\ominus}{=}$ & \begin{tabular}{l}
8 \\
8 \\
\hdashline
\end{tabular} & $\begin{array}{l}8 \\
\text { \& } \\
\text { m. }\end{array}$ & \begin{tabular}{l}
8 \\
8 \\
\multirow{+}{*}{} \\
$i$
\end{tabular} & $\begin{array}{l}\hat{\sigma} \\
\stackrel{0}{0} \\
0\end{array}$ & \begin{tabular}{l}
8 \\
$\stackrel{2}{n}$ \\
\hdashline
\end{tabular} & $\begin{array}{l}\infty \\
\stackrel{9}{+} \\
\text { m. } \\
0\end{array}$ & $\begin{array}{l}\mathscr{\Xi} \\
=\end{array}$ & $\begin{array}{l}8 \\
8 \\
8 \\
\text { m. }\end{array}$ & $\begin{array}{l}8 \\
\curvearrowleft \\
=\end{array}$ & $\begin{array}{l}8 \\
8 \\
8\end{array}$ & $\begin{array}{l}\text { तె } \\
\text { గె } \\
0\end{array}$ & $\frac{\stackrel{d}{I}}{0}$ & 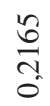 & $\begin{array}{l}\hat{a} \\
\tilde{n} \\
\hat{0}\end{array}$ & $\frac{n}{\frac{f}{0}}$ & \\
\hline$\stackrel{\theta}{2}$ & 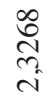 & $\begin{array}{l}8 \\
8 \\
\text { } \\
\text { f }\end{array}$ & $\begin{array}{l}8 \\
8 \\
\text { r. } \\
\text { r. }\end{array}$ & $\frac{\sqrt[n]{n}}{n}$ & $\begin{array}{l}\text { ले } \\
\stackrel{n}{n}\end{array}$ & $\begin{array}{l}\infty \\
\underset{\sim}{\sim} \\
\stackrel{-}{-1}\end{array}$ & $\frac{8}{2}$ & $\begin{array}{l}8 \\
8 \\
n \\
\text { n. }\end{array}$ & 8 & 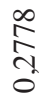 & $\begin{array}{l}8 \\
\text { Dn } \\
\text { in } \\
0\end{array}$ & $\frac{n}{\frac{n}{n}}$ & 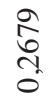 & 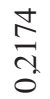 & $\begin{array}{l}\text { oे } \\
\text { in } \\
\text { o }\end{array}$ & \\
\hline$\infty$ & $\begin{array}{l}\text { D. } \\
\text { तn } \\
\text { ?n }\end{array}$ & $\frac{8}{8}$ & $\begin{array}{l}\text { \& } \\
\stackrel{+}{+}\end{array}$ & $\frac{\sqrt{3}}{\tilde{n}}$ & $\begin{array}{l}\tilde{m} \\
\approx \\
\approx \\
0\end{array}$ & $\begin{array}{l}8 \\
\text { o } \\
\text { లn } \\
0\end{array}$ & $\begin{array}{l}\stackrel{2}{2} \\
\text { ర్ } \\
0\end{array}$ & 8 & $\frac{\hat{0}}{0}$ & $\begin{array}{l}\sqrt{0} \\
\frac{0}{0}\end{array}$ & $\begin{array}{l}n \\
\stackrel{0}{0} \\
0\end{array}$ & $\begin{array}{l}\text { 이 } \\
8 \\
8 \\
0\end{array}$ & $\begin{array}{l}\hat{0} \\
\stackrel{n}{0} \\
0\end{array}$ & $\frac{0}{m}$ & $\frac{\stackrel{n}{n}}{0}$ & \\
\hline N & $\begin{array}{l}\overline{0} \\
\infty \\
\sim\end{array}$ & \begin{tabular}{l}
8 \\
8 \\
$n$ \\
\multirow{2}{*}{}
\end{tabular} & $\begin{array}{l}8 \\
\text { ஓ } \\
\text { m. }\end{array}$ & 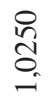 & 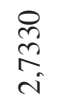 & 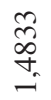 & 8 & $\begin{array}{l}8 \\
8 \\
n \\
0\end{array}$ & 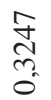 & $\begin{array}{l}0 \\
\infty \\
\infty \\
\dddot{m} \\
0\end{array}$ & 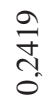 & $\frac{\stackrel{N}{f}}{0}$ & $\begin{array}{l}\sqrt{n} \\
\text { ?n} \\
0\end{array}$ & $\begin{array}{l}\overrightarrow{+} \\
\text { సે } \\
0\end{array}$ & $\begin{array}{l}\overline{\widetilde{\Omega}} \\
\tilde{n} \\
0\end{array}$ & \\
\hline 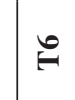 & $\begin{array}{l}\text { ర్ } \\
\text { రె. } \\
\text { m. }\end{array}$ & $\frac{8}{8}$ & $\begin{array}{l}8 \\
8 \\
8\end{array}$ & $\begin{array}{l}\text { §్ర } \\
\text { ડু }\end{array}$ & $\frac{8}{\stackrel{8}{~}}$ & 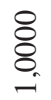 & $\frac{\sqrt{2}}{n}$ & $\begin{array}{l}\text { त̃ } \\
\infty \\
\end{array}$ & $\begin{array}{l}\hat{\sigma} \\
\stackrel{0}{0}\end{array}$ & 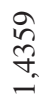 & $\begin{array}{l}\hat{b} \\
\stackrel{2}{+} \\
\dot{\sigma}_{0}\end{array}$ & $\begin{array}{l}\overline{0} \\
\text { ते } \\
0\end{array}$ & $\begin{array}{l}\stackrel{0}{\infty} \\
\infty \\
0\end{array}$ & 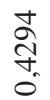 & $\begin{array}{l}\stackrel{\infty}{\mathbb{N}} \\
\underset{\sim}{-}\end{array}$ & \\
\hline$n$ & $\begin{array}{l}8 \\
\stackrel{n}{n} \\
n\end{array}$ & $\underset{8}{8}$ & $\begin{array}{l}8 \\
8 \\
\stackrel{1}{0} \\
\text { i }\end{array}$ & $\begin{array}{l}\hat{\sigma} \\
=\end{array}$ & 8 & $\begin{array}{l}\stackrel{0}{=} \\
\stackrel{0}{0}\end{array}$ & 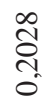 & $\frac{N}{n}$ & 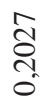 & $\begin{array}{c}m \\
\stackrel{m}{m} \\
0\end{array}$ & 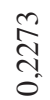 & $\frac{i 0}{0}$ & $\begin{array}{l}m \\
m \\
m \\
0\end{array}$ & 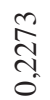 & $\frac{\stackrel{n}{\underset{f}{f}}}{\underset{0}{\sigma}}$ & $\frac{\mathfrak{a}}{\sigma}$ \\
\hline$\underset{F}{ \pm}$ & $\begin{array}{l}8 \\
\text { ते } \\
\text { तi }\end{array}$ & $\begin{array}{l}8 \\
8 \\
i \\
\text { in }\end{array}$ & $\begin{array}{l}8 \\
\delta \\
0 \\
\dot{\sigma}\end{array}$ & $\underset{8}{8}$ & 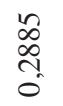 & $\frac{\hat{a}}{\hat{O}}$ & $\begin{array}{l}\text { Jै } \\
\stackrel{f}{\sigma} \\
0\end{array}$ & $\begin{array}{l}\text { ลे } \\
\text { ڤ్ }\end{array}$ & 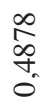 & $\begin{array}{l}\text { ले } \\
\text { के } \\
\text { o. }\end{array}$ & 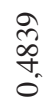 & $\underset{\text { సे }}{\stackrel{\text { సू }}{0}}$ & 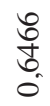 & 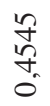 & $\begin{array}{l}\text { Ni } \\
\frac{\infty}{0} \\
\tilde{0}\end{array}$ & 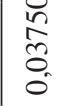 \\
\hline$\ddot{\theta}$ & 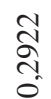 & \begin{tabular}{l}
8 \\
8 \\
\multirow{+}{*}{} \\
i
\end{tabular} & 8 & $\frac{8}{\equiv}$ & $\frac{\infty}{\stackrel{\infty}{-}}$ & $\begin{array}{l}\text { Oे } \\
\mathscr{O}_{0} \\
0\end{array}$ & $\begin{array}{l}\stackrel{2}{\infty} \\
\stackrel{m}{0} \\
0\end{array}$ & 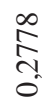 & $\begin{array}{l}\text { bo } \\
\stackrel{\mathscr{n}}{0}\end{array}$ & $\begin{array}{l}\stackrel{0}{\infty} \\
\stackrel{0}{0}\end{array}$ & $\underset{0}{\stackrel{F}{ \pm}}$ & $\begin{array}{l}\text { 이 } \\
8 \\
0 \\
0\end{array}$ & 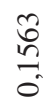 & $\frac{\vec{J}}{0}$ & \begin{tabular}{l}
8 \\
\multirow{2}{n}{} \\
0 \\
0
\end{tabular} & \\
\hline$\widetilde{N}$ & 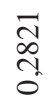 & 8 & $\frac{\infty}{\stackrel{\infty}{-}}$ & $\begin{array}{l}\text { तु } \\
\text { ᄋ̆ } \\
0 \\
0\end{array}$ & $\frac{8}{\stackrel{\circ}{\Xi}}$ & $\begin{array}{l}\vec{\infty} \\
\stackrel{0}{0} \\
0\end{array}$ & $\frac{\stackrel{2}{3}}{\stackrel{0}{0}}$ & 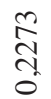 & $\frac{0}{\frac{\pi}{0}}$ & $\begin{array}{l}\stackrel{2}{ } \\
\stackrel{0}{0} \\
\overrightarrow{0}\end{array}$ & $\frac{0}{\frac{\pi}{0}}$ & 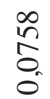 & $\begin{array}{l}2 \\
\stackrel{\infty}{0} \\
\stackrel{0}{0}\end{array}$ & $\begin{array}{l}\stackrel{0}{0} \\
\stackrel{0}{0}\end{array}$ & $\frac{\overparen{a}}{\stackrel{\sigma}{0}}$ & 串 \\
\hline$\vec{E}$ & 8 & $\begin{array}{l}\text { ஜ } \\
0 \\
\text { in }\end{array}$ & $\frac{\pi}{\sigma}$ & 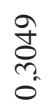 & 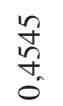 & $\begin{array}{l}\frac{n}{0} \\
0 \\
0\end{array}$ & 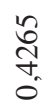 & $\begin{array}{l}\text { ลे } \\
\text { กิ }\end{array}$ & $\begin{array}{l}\stackrel{+}{2} \\
\text { లె. } \\
0 \\
0\end{array}$ & $\begin{array}{l}\stackrel{n}{f} \\
\stackrel{+}{f} \\
0 \\
0\end{array}$ & $\begin{array}{l}\text { +े } \\
\text { ले } \\
0\end{array}$ & $\begin{array}{l}\text { N } \\
\text { त̂ } \\
0\end{array}$ & 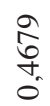 & $\frac{N}{n}$ & $\begin{array}{l}\Re \\
\stackrel{0}{+} \\
\stackrel{+}{-}\end{array}$ & : \\
\hline & $E$ & $\tilde{N}$ & $\ddot{\theta}$ & $\underset{\theta}{ \pm}$ & $\mathscr{n}$ & $\ddot{H}$ & F & $\stackrel{\infty}{\mathscr{H}}$ & $\hat{\theta}$ & $\stackrel{ }{\underline{\theta}}$ & $\exists$ & $\mathcal{G}$ & $\stackrel{m}{G}$ & $\underset{G}{ \pm}$ & $\stackrel{n}{\mathscr{n}}$ & نี \\
\hline
\end{tabular}


Within the scope of the study, 15 factors that may lead to rejection of destination are determined by content analysis from data gathered from the tourism experts, and the significance degrees of these factors with regard to the behaviour of destination rejection are found through AHP method. When the findings are examined, it is seen that the most significant factors that may lead to corresponding behaviour that tourist consumers may develop against a destination within their decision making process of purchase are "Terrorist activities in the country or in close neighborhood" and "High rate of crime in the destination". In the study, although terrorist activities and destination crime are examined under different headings, terrorist activities are the activities regarded as criminal activities essentially. When viewed from this aspect, the most important reason of rejection behaviour that may be developed against a destination may be said to be the crime rates existing in that destination.Another important factor is health risks that consumers perceive. This factor is also among the most significant factors that may lead the behaviour of destination rejection.

In the study, it is aimed to explain the concept of destination rejection and reveal legal crime rate that leads to destination rejection. In the study, the factors that may lead to destination rejection by opinions of experts within tourism sector are sorted according to their level of significance. So that this study guides future studies, by making a special assessment for a certain destination this study will contribute to the decision making mechanism for that destination. Determination of anti-consumption criteria is a condition necessary to identify ways to cope with these problems. On the other hand, this study is significant in finding the answer to the question of why some parts of the market do not prefer the destination.

\section{Limitations and Future Agenda}

Despite the contribution of this paper, there are some limitations. Identifying the ideas of individuals who do not visit the destination is quite difficult. For this reason, in this study, the ideas of experts (expecialy decision makers in tourism industry) are uncovered in terms of the concept of destination rejection.

For the methodological choice of this study, data collection process was costly, required too much effort, time. Hence only a limited set of tourism professionals shared their perceptions. There is an opportunity for future studies seeking to identify why some individuals are rejecting to travel to a definite destination by expanding to incorporate consumers' views as well. Additionally, there is another opportunity to identify the destination rejection behaviour of a local people to definite touristic destination.

\section{References}

Alleyne, D. \& Boxill, I. (2003). The impact of crime on tourist arrivals in Jamaica. International Journal of Tourism Research, 5(5), 381- 391.

Alonso, J. A. \& Lamata, M. T. (2006). Consistency in the analytic hierarchy process: A new approach. International Journal of Uncertainty, Fuzziness and Knowledge-Based Systems, 14(04), 445-459. 
Austin, C. G., Plouffe, C. R., \& Peters, C. (2005). Anti-commercial consumer rebellion: Conceptualisation and measurement. Journal of Targeting, Measurement \& Analysis for Marketing, 14(1), 62-78.

Berrittella, M., La Franca, L., \& Zito, P. (2009). An analytic hierarchy process for ranking operating costs of low cost and full service airlines. Journal of Air Transport Management, 15(5), 249- 255.

Bottero, M., Comino, E., \& Riggio, V. (2011). Application of the analytic hierarchy process and the analytic network process for the assessment of different wastewater treatment systems. Environmental Modelling \& Software, 26(10), 1211-1224.

Cherrier, H. (2009). Anti-consumption discourses and consumer- resistant identities. Journal of Business Research, 62(2), 181- 190. doi: 10.1016/j.jbusres.2008.01.025.

Choi, S.H. (2011). Anti-consumption becomes a trend. SERI Quarterly, 4(3), 117-120.

Delacote, P. \& Montagné-Huck, C. (2012). Political consumerism and public policy: Good complements against market failures? Ecological Economics, 73, 188-193. doi: 10.1016/j.ecolecon.2011.10.020

Fujii, E. T. \& Mak, J. (1979). The impact of alternative regional development strategies on crime rates: Tourism vs. agriculture in Hawaii. The Annals of Regional Science, 13(3), 42-56.

Iyer, R. \& Muncy, J. A. (2009). Purpose and object of anti- consumption. Journal of Business Research, 62(2), 160-168. doi: 10.1016/j.jbusres.2008.01.023

Kutvan, A. B., \& Kutvan, S. A. (2013). Turizm planlamasinda destinasyon çekiciliklerinin ölçümü: Bir yöntem yaklaşimi. (Turkish). Measurement Of Destination Attractiveness In Tourism Planning: A Method Approach.(English), 6(11), 159- 183.

Larsen, S., Brun, W .\& Øgaard, T. (2009). What tourists worry about-Construction of a scale measuring tourist worries. Tourism Management, 30(2), 260-265.

Lawson, R. \& Thyne, M. (2001). Destination avoidance and inept destination sets. Journal of Vacation Marketing, 7(3), 199.

Lee, M. S. W. Fernandez, K. V., \& Hyman, M. R. (2009). Anti- consumption: An overview and research agenda. Editorial. Journal of Business Research, pp. 145147. Retrieved from http://search.ebscohost.com/ login.aspx?direct=true \&db=bth\& $\mathrm{AN}=36016410 \&$ lang $=$ tr\&site $=$ ehost-live

Lee, M. S. W., Motion, J. \& Conroy, D. (2009). Anti-consumption and brand avoidance. Journal of Business Research, 62(2), 169-180. doi: 10.1016/j.jbusres.2008.01.024

Ömürbek, N. \& Tunca, M. Z. (2013). Analitik hiyerarşi süreci ve analitik ă̆ süreci yöntemlerinde grup karari verilmesi aşamasina ilişkin bir örnek uygulama. Suleyman Demirel University Journal of Faculty of Economics \& Administrative Sciences, 18(3), 47-70.

Özalpman, D. (2010). Bir temellendirilmiş kuram denemesi: Politik amaçla marka seçen tüketici yönetimi. İstanbul Üniversitesi İletişim Fakültesi Dergisi, 2(39), 119.

Penaloza, L. \& Price, L. L. (1993). Consumer resistance: A conceptual overview. Advances in Consumer Research, 20(1), 123-128. 
Roux, D. (2007). Consumer resistance: Proposal for an integrative framework. Recherche et Applications en Marketing (English Edition) (AFM c/o ESCP-EAP), 22(4), 59-79.

Saaty, T.L. (2003). Decision-making with the AHP: Why is the principal eigenvector necessary. European journal of operational research, 145(1), 85-91.

Shaw, D. \& Moraes, C. (2009). Voluntary simplicity: an exploration of market interactions. International Journal of Consumer Studies, 33(2), 215-223. doi: 10.1111/j.14706431.2009.00760.x

Sönmez, S. F. \& Graefe, A. R. (1998). Determining future travel behavior from past travel experience and perceptions of risk and safety. Journal of Travel Research, 37(2), 171177.

Sönmez, S. F. \& Graefe, A. R. (1998). Influence of terrorism risk on foreign tourism decisions. Annals of Tourism Research, 25(1), 112-144.

Urfalığlu, F. T. \& Genç, T. T. (2013). Çok kriterli karar verme teknikleri ile Türkiye'nin ekonomik performansının Avrupa birliği üye ülkeleri ile karşılaştırılması. Marmara Üniversitesi İktisadi ve İdari Bilimler Fakültesi Dergisi, (2), 329.

Van Tran, X. \& Bridges, F. S. (2009). Tourism and crime in European nations. e-Review of Tourism Research, 7(3), 52-67.

Wind, Y. \& Saaty, T. L. (1980). Marketing Applications of the Analytic Hierarchy Process. Management Science, 26(7), 641-658.

Ventura, K. (2013). Marka kaçınması: Beyaz eşya markalarına yönelik kalitatif bir uygulama. Uluda ̆̈ Üniversitesi İktisadi ve İdari Bilimler Fakültesi Dergisi, 32(1), 53.

Saaty, Thomas L., \& Vargas, Luis G. (2012). Models, methods, concepts \& applications of the analytic hierarchy, springer. 
